\title{
Biography of Contributors
}

\begin{abstract}
Alexander Álvarez Fonseca
Born on 21 November 1976, Alexander graduated as an agricultural engineer from Granma University in 2010. Gaining a Master's in Agricultural Sciences in 2016, he works at Jorge Dimitrov Agricultural Research Institute, Bayamo, Granma, Cuba, carrying out investigations on the laser and ionising radiation effects on seeds, with several scientific articles published in refereed reviews. He participates in the Local Agricultural Innovation Program, leading the participatory plant breeding studies in the eastern region of Cuba, which is involved with many research and technological innovation projects.
\end{abstract}

\section{Luis Enrique Arias Basulto}

Luis Enrique Arias Basulto graduated as an agricultural engineer from the Higher Institute of Agricultural Sciences of Bayamo (ISCAB) in 1984 (today Granma University). An auxiliary researcher in 2002, he gained a Master's in Agricultural Sciences in 2003. From 1985 to 2006, he was a researcher at the Jorge Dimitrov Agricultural Research Institute, conducting research such as the establishment of the institution's fruit tree germplasm bank, setting up and conducting experiments in coffee cultivation related to the management of new plantations and established plantations, considering pruning, shade regulation and planting density, as well as the study of different coffee genotypes resistant to rust. He became Assistant Professor in 2007 at the University of Granma. He has undertaken more than 40 postgraduate courses and is author and co-author of 17 scientific publications. He has been the tutor of several undergraduate theses and taught seven postgraduate courses.

\section{Pedro Boff}

Pedro Boff is the great-grandson of Italian immigrants in southern Brazil, where he helped out on his family farm. He graduated in agronomy (1983), followed by a Master's degree in phytopathology, joining EPAGRI-Agriculture Research and Extension Rural Service of Santa Catarina, southern Brazil, in 1988, where he works as a researcher linked to the Lab of Homeopathy and Plant Health until today. After 4 years of direct contact with farmers, he realised that the industrial technologies were leaving farmers more dependent than ever on pesticides. So he returned to study, first, agroecology (1992), and then to gain a doctorate in biological control from Wageningen University (1997-2001). Soon after, he realised that the widespread application of biological controls could be as dangerous as chemicals and that farmers needed inputs that were easy to access and of low cost. He came across biodynamic farming, and from there agricultural homeopathy, to which he has been dedicated since 2005 to the present, chiefly through research and supervising MSc and $\mathrm{PhD}$ theses students. Pedro collaborates in disciplines of integrative homeopathy at UDESC and UNIPLAC universities in Santa Catarina State, Brazil. He coordinates courses of integrative and popular homeopathy for farmers, technicians, researchers, students and the public in Brazil. His commitment to homeopathy is to guarantee free access to farmers, without it being appropriated exclusively by corporations and/or professional classes. Parallel with this, he also runs an organic viticulture farm in his own area (https://www.epagri.sc.gov.br/).

\section{Janus Bojesen Jensen}

Already holding an MSc in Organic Farming, Janus's current research topic is 'An Exploration of Subtle Agroecological Practices for the Decolonisation of Agriculture', and he investigates the potential of non-material, energetic practices to enhance organic and agroecological farming systems worldwide. Janus has previously conducted research in India with the Brahma Kumaris Rural Development Wing and is keenly interested in exploring the links between spirituality, ecology and 
agriculture. He lives in London, UK, and in his free time enjoys natural beekeeping, learning rural skills and horticulture, building on his certification in permaculture design. He is also restoring a seventeenth-century farm on Bornholm Island, Denmark, with the intention of transforming it into a demonstration ahimsa (sacred) farm and teaching centre for Subtle Agroecology.

\section{Isis Brook}

Isis Brook completed a $\mathrm{PhD}$ on Goethean science following training with the Life Science Trust in the UK in the early 1990s. She has been a university lecturer for over 25 years, mainly teaching environmental philosophy and aesthetics, and is author of numerous research papers in these areas. Her most recent post was with Crossfields Institute, in Stroud, UK, where she was involved in designing and teaching on their innovative Masters programme 'Researching Holistic Approaches to Agroecology'. Isis is now semi-retired and as a Research Fellow continues to write on phenomenology, plants, landscapes and Goethe's approach to nature. However, a lot of her time is now spent in the garden and on her allotment.

\section{Simon Charter}

After obtaining a degree in Applied Physics, expeditions to Norway, Africa and India, and voluntary work, Simon spent 4 years working in biodynamic farming and social education in Botton Village Camphill Community in the UK. After further training in art therapy, he started working with water in the environment, where his artistic, ecological and practical interests flowed together. For 30 years, this has focused on landscape projects with Flowform water sculptures as pioneered by John Wilkes. Through the company Ebb \& Flow Ltd, these projects have included sewage treatment systems and work in agriculture, therapeutic and educational environments and in gardens. Interest in the challenge of the single-bowl Flowform idea, as discovered by Philip Kilner, led Simon to develop his own Flowform designs which are being made in glass, ceramic, cast stone and metal. Simon completed a Master's in education in 2014, researching the way people develop through engaging creatively with the element of water. He undertakes independent and collaborative research into flow phenomena and runs Goethean science workshops that explore the nature of water (following Theodor Schwenk's approach). He organises courses on basic Projective Geometry and on the path curves found in natural form (as revealed by Lawrence Edwards). Simon and his wife Cate also take guests in their house on an old mill site with much clear flowing water, its own hydropower and a water-driven heat pump (flowoflife.org; ebbandflowltd.co.uk).

\section{Mike Zeddy Chikukwa}

Zeddy Chikukwa grew up in Chikukwa, Zimbabwe, always needing to be in nature, exploring the connections between our natural world and village life. He started as a community volunteer in 2005 and, since 2009, has worked for the Chikukwa Ecological Land Use Trust as a youth activist and advocate, initiating environmental management action groups. His interests are rooted in his cultural traditions, which led him to establish the Culture Group consisting of spirit mediums, traditional healers, herbalists and other knowledge holders, learning together about his cultural heritage that has been lost since colonial times. Being the youngest in the group, he noticed that the elders needed a listening ear, to preserve and revive their rituals and practices, and investigate how these can help them to become more resilient in these changing times - from what and how they grow the crops they eat, to the way they harvest, process and store. Over time, he has been motivated to learn about our natural laws and spirit connections, and work towards the preservation of his lands and sacred sites. His dreams and hopes are that through a better understanding of spirituality and place, everyone might heal the wounds of Mother Earth.

\section{Travis Cox}

Dr Cox's interests and research are about the intersections of social movements and social justice, education, metaphysics, psychedelics, environmental philosophy, agriculture and deep sustainability. 
He is currently an Associate Professor in the undergraduate school and in the Ecopsychology MA (where he was former chair) at Naropa University - a Buddhist-inspired fully accredited university in Boulder, Colorado. He has taught environmental humanities in the BA and MA programmes in Sustainable Living at Maharishi University of Management in Fairfield, Iowa, and was codirector of the BA for 2 years. Dr Cox earned his $\mathrm{PhD}$ in Sustainable Agriculture at Iowa State University; a Master's in Philosophy and Religion, with an emphasis in Philosophy, Cosmology and Consciousness, from the California Institute of Integral Studies; and a Bachelor's in Philosophy from Central College in Pella, Iowa.

\section{Jude Currivan}

Dr Jude Currivan is a cosmologist, planetary healer, author, previously one of the most senior business women in the UK and co-founder of WholeWorld-View. She has experienced multidimensional realities since early childhood, travelled to over eighty countries and worked with wisdom keepers of many traditions. She integrates leading-edge science, consciousness research and universal wisdom teachings into a wholistic worldview, underpinning her work to enable transformational and emergent resolutions to our collective planetary issues. She holds a $\mathrm{PhD}$ in Archaeology from the University of Reading in the UK researching ancient cosmologies and a Master's Degree in Physics from Oxford University specialising in cosmology and quantum physics. International author of six non-fiction books, her latest is Nautilus award-winning The Cosmic Hologram: In-formation at the Center of Creation, the first book of the Transformation trilogy. She is currently writing book two Gaia: Her-Story. In 2010, she was presented with a CIRCLE Award by WON Buddhism International for her 'outstanding contribution towards planetary healing and expanding new forms of consciousness'. She is a member of the Evolutionary Leaders Circle (www.evolutionaryleaders. net) and in 2017 co-founded WholeWorld-View (www.wholeworld-view.org) to empower the understanding, experiencing and embodying of unity awareness in service to conscious evolution (www. judecurrivan.com).

\section{Saskia G. von Diest}

Saskia von Diest is a facilitator, educator, consultant and researcher of 'ecofluency' - intuitive, interspecies communication with the rest of Nature, as a vital way of knowing and a resource for harmonious relationship with all life - https://www.ecofluency.org/. After completing her PhD in plant pathology (2013), she held a postdoctoral fellowship (2014-2017) at Stellenbosch University, South Africa, to investigate quantum-based agricultural techniques and technologies that use sound, electromagnetics and intuitive abilities in management decision-making. Her passion for knowledge extension inspired her to bring various international experts to host workshops in South Africa, and to help build an international network of farmers, technical advisors and researchers for this emerging field of research. Saskia further explored intuitive farming in a collaborative postdoctoral project (2018-2020), between the Centre for Complex Systems in Transition (CST) and the Department of Conservation Ecology and Entomology at Stellenbosch University, and the Centre for Agroecology, Water and Resilience (CAWR) at Coventry University, UK. She presents her work in various forms on numerous international platforms, and facilitates embodied experiences of how dialogue with the rest of nature can practically benefit decisions, from food growing to personal development (https://www.ecofluency.org/).

\section{Paul Doesburg}

Paul Doesburg holds a BSc in medical biotechnology. Paul became acquainted with the copper chloride crystallisation method during his employment at the Louis Bolk Institute where he worked from 2001 to 2009 on the standardisation, validation and application of this method within a European context. In 2010, he started a private company, Crystal Lab, to continue this work. Since 2010, he has been a member of the board of the King Fisher Foundation, a Dutch foundation for phenomenology and Goethean science. Paul's vision is a world in which wholeness and resilience 
are leading principles in healthcare and nutrition. To this end, he co-authored the book Barstensvol leven: een pleidooi voor vitale voeding ('Full of Life: a Plea for Vital Food'), which focuses on a systemic perspective towards food quality; its relation to resilience; new research methodologies that address this aspect; a new concept of health which emphasises resilience and makes a direct link feasible between vital food and health; and the policy implications with respect to the production of vital food and the development of (high-tech) sustainable agriculture. Paul is a $\mathrm{PhD}$ candidate at since 2017 the Witten/Herdecke University, Germany, focusing on fundamental homeopathic research in combination with the crystallisation method. Since 2020 he has been working at the Society for Cancer Research at the Hiscia Research Institute in Arlesheim, Switzerland (https:// www.crystal-lab.nl/ and https://www.iscador.com/en/).

\section{Michel Duhamel}

Michel Duhamel was educated in mechanical engineering (Supmeca Institute, Paris) and graduated in social psychology (Paris-X University). He has a diversified experience in the development of new activities, which he practised during 14 years at Bossard Consultants (1971-1985), was then the first French group of management consultants; subsequently 6 years at Nodal Consultants (business development strategies through innovation and partnership) (1991-1996); and 5 years at Erdyn Consultants (scientific and technical consulting) (1997-2001). He is co-founder and chairman of Genodics SAS, since May 2008, and Multinno SARL (Paris; 2010). He has also strategically contributed to the establishment of the European Association for the Transfer of Technologies, Innovation and Industrial Information (T.I.I., Luxembourg), of which he was Secretary General from 1986 to 1990 and President from 2006 to 2009. His main areas of expertise are the creation of new businesses, innovation management, economic development policies, industrial and administrative management, human relations and change management, the development of genodics - a new approach to biology through protein music - and the production of scientific publications.

\section{Miche Fabre Lewin and Flora Gathorne-Hardy}

Dr Miche Fabre Lewin and Dr Flora Gathorne-Hardy are co-founders of Touchstones Earth ecological arts and research practice. Their work comprises multimedia rituals, choreographies, installations, artworks and forums to engage the senses and amplify our capacities for thinking-feeling with each other and Earthly sentience. These emergent encounters open us to experiences of life as a connecting force, inspiring refreshed narratives and cooperative partnerships for responsible and liberatory action in the world. Within her research, Miche Fabre Lewin has evolved sympoiethics as the conjoining of sympoiesis and ethics, where sympoiesis defines life as a process of 'makingwith' between human cultures and an animate world. Sympoiethics is a responsive, life-affirming orientation that attends to the multiplicity of bodymind experiences, the diversity of human bodies of culture, and the multifold 'voices' of the planetary body. Touchstones Earth is in alliance with the transdisciplinary research Centre for Agroecology, Water and Resilience (CAWR) at Coventry University, the Sustainability Institute, Lynedoch, South Africa and the Centre for Complex Systems in Transition, Stellenbosch University, where both Miche and Flora are Artist Research Associates (www.touchstones.earth).

\section{Leonardo Felipe Faedo}

Leo is Brazilian, graduating in agronomy from the Santa Catrina State University (UDESC) in the Agroveterinarian Science Centre (CAV), in 2012, with a specialism in Agribusiness Administration from the Federal University of Paraná (UFPR) in 2015. He then worked with conventional horticulture, fruticulture and cereal crops, and this experience made him change his perspective on agriculture since which he has focused on agroecology. This led to a Master's in Plant Production focusing on homeopathy and biological control of plant diseases on the strawberry crop (UDESC), in 2018, and he is currently a Co-tutelle PhD student on Plant Production at both the Santa Catarina State 
University (UDESC) and the Centre for Agroecology, Water and Resilience (CAWR), Coventry University, UK, where he is focusing on homeopathy applied to plants and biodynamic farming methods to increase the vitality of farming systems. Leo is a member of the Laboratories of Fruticulture at the CAV/UDESC, focusing on strawberry crops, and the Laboratory of Homeopathy and Plant Health at the Institute for Research and Rural Extension of Santa Catarina State (EPAGRI). $\mathrm{He}$ is also a permaculture designer; organic farming advisor; homeopathic agronomist; biodynamic agronomist; and editor of the Brazilian Agroecology Journal. His intention is to promote agroecological food systems worldwide, to help to build green agriculture and make healthy, nutritional food available for all.

\section{Pedro Ferrandiz}

Pedro Ferrandiz gained engineering qualifications at the Pierre and Marie Curie University (UPMC), Paris, in 1993. Prior to that, in 1991, he had started undertaking independent research in genodics, supervised by Joël Sternheimer, inventor of this discipline. The first experiments were on plants and in bread-making, resulting in the article: Process of epigenetic regulation of protein synthesis - trial in bread-making, Industrie des Céréales, No. 85, December 1993, p. 40, https://aemic.com/blog/ article/procede-de-regulation-epigenetique-de-la-synthese-proteique-essai-en-panification.html. From 1994 to 2008, he worked as Production Engineer, Group Industrial Controller and Group Supply Chain Manager at the Evry site of the Jacquet Group (France). In 1999, he was a founding member of the R.A.Ch.I (Réseau Associatif de Chercheurs Indépendants), undertaking research work, the development of applications and conferences and publications on genodics. In 2008, he became Executive Director of Genodics SAS (Paris), with the objective of providing evidence of genodics through concrete applications in the field, particularly in agriculture. In 2020, 170 farmers used this process, over 2,500 ha, with around 40 applications. He leads on the research, distribution, installation and monitoring of applications as well as partnerships with research teams.

\section{Bertus Haverkort}

Bertus Haverkort has worked for several decades in agricultural and rural development programmes in Colombia, Bolivia, Ghana and India. He has been Manager of ILEIA (www.ileia.org) and has worked in the ETC Foundation. More recently, he has been Visiting Professor at the University for Developing Studies in Ghana. Bertus is author/co-author of several books including the following: Towards Co-Creation of Sciences: Building on the Plurality of Worldviews, Values and Methods in Different Knowledge Communities (2012); Ancient Roots, New Shoots: Endogenous Development in Practice (2003); Food for Thought: Ancient Visions and New Experiments of Rural People (1999); Linking with Farmers: Networking for Low-External-Input and Sustainable Agriculture (1993); Farming for the Future: An Introduction to Low-External-Input and Sustainable Agriculture (1992); and Joining Farmer's Experiments: Experiences in Participatory Technology Development (1991).

\section{Pedro Jovchelevich}

Pedro Jovchelevich is an agronomist with a Master's degree (moon rhythms in biodynamic horticulture) and a $\mathrm{PhD}$ in biodynamic plant breeding. Pedro is General Manager of the Brazilian Association of Biodynamic Agriculture (ABD), teacher of the Brazilian biodynamic course and coordinator of ABD's Participatory Guarantee System and the biodynamic seed network. He is 52 years old and married and has three children. He lives in the countryside in Botucatu, SP, Brazil (www.biodinamica.org.br).

\section{Eline Kieft}

Eline Kieft has danced from a young age, including rigorous classical and contemporary training to become a professional dancer. She explored indigenous ways of knowing through her studies in anthropology (BA, MA). During her PhD in Dance at Roehampton University, London, she 
looked at dance as a modality for healing and spirituality, including embodied epistemologies and shamanic techniques. From 2015 to 2020, she worked at the Centre for Dance Research (C-DaRE) at Coventry University where she designed a Somatics Toolkit for Ethnographers to use the body within the research cycle. She is a long-term shamanic practitioner and student of Jonathan Horwitz, as well as a qualified teacher of Movement Medicine, an approach for contemporary shamanic improvised dance. Finally, Eline is a certified Holden Qi Gong instructor. All these experiences are woven into her freelance company Clover Trail, a place where people can reconnect with what helps them thrive in life. This includes various movement practices, nature immersion, shamanic and lucid-dreaming techniques, tools for embodied knowing, sacred art-making, ceremony and transformation (http://www.clover-trail.com).

\section{Hugh Lovel}

Hugh Lovel (1947-2020) was a farmer and an international consultant to dairy farms, graziers, broadacre grain growers and fruit and vegetable producers. As a multidisciplinary scientist, Hugh introduced comprehensive soil testing using both the Albrecht approach and a total acid digest test that more clearly revealed what is actually present in soils. Above all, he was a leading pioneer of the new science of Quantum Agriculture. Hugh Lovel authored A Biodynamic Farm, for Growing Wholesome Food and Quantum Agriculture: Biodynamics and Beyond. He was the original designer of the Field Broadcaster quantum technology and the Quantum Radionic Analyser. His articles have appeared in Acres USA and related organic farming periodicals such as Acres Australia and biodynamic journals around the world. Hugh's work and legacy are being continued in the capable hands of his widow, Shabari Bird Lovel (www.quantumagriculture.com).

\section{Patrick MacManaway}

Dr Patrick MacManaway is a third-generation practitioner of psychic and healing arts. A graduate of Edinburgh University Medical School, he is a former President of the British Society of Dowsers and the author of several books and CDs. He consults and teaches land whispering in the UK, the USA and Australia (www.patrickmacmanaway.com).

\section{Charles Massy}

Charles Massy gained a BSc (Zoology, Human Ecology) at the Australian National University (ANU, 1976), before going into farming for over 40 years. This included the development of a prominent Merino sheep genetics business ('Severn Park'). Concern over ongoing land degradation and humanity's sustainability challenge led him to return to ANU to undertake a PhD in Human Ecology, completed in 2013. Charles has chaired and served as a director on a number of national and international businesses, research organisations, review panels and statutory wool boards, involving garment manufacture, wool marketing, R\&D, molecular genetics and genomics. Charles has had five books published, including two on Merino history (Penguin and Random House) and one on the political destruction of the Australian wool industry (Breaking the Sheep's Back 2011, UQP), and in 2017, he published the best-selling Call of the Reed Warbler: A New Agriculture, a New Earth (UQP and Chelsea Green). This book has become a talisman for the regenerative agriculture movement and has won and been shortlisted for a number of literary awards. Massy has also engaged in freelance journalism since 1977 across a range of subjects from mountaineering, ecology, history, sheep and wool, research management, plus fiction short stories and poetry. He continues to manage a sheep and cattle grazing property, while consulting widely in the fields of Merino breeding, transformative change in agriculture, and in landscape design.

\section{Georgina McAllister}

With an NGO background since the early 1990s, George's experience spans both the humanitarian and development sectors in Europe, the Middle East, South-East Asia, Pacific and sub-Saharan 
Africa. It was this engagement with the on-the-ground realities of those affected by ongoing political instability, social division and shattered infrastructure that first drew her to agroecology. Now as assistant professor in Stabilisation Agriculture at the Centre for Agroecology, Water and Resilience, George applies a regenerative lens to food and farming systems in disaster-prone and conflict-affected environments, with a specific interest in the transformation of social-ecological relationships rooted in social farming. This work explores the extent to which small 'non-movements' employ non-threatening, practice-based co-learning processes not only to shape physical landscapes, but to negotiate social change by re-forging networks based on principles of reciprocity and trust.

\section{Gudrun Mende}

Gudrun Mende (Dipl.Chem) has been working at KWALIS since 1997. She was introduced by Jürgen Strube to the measuring technology of fluorescence excitation spectroscopy (FES) and is involved with the dependencies of the measurement methodology, the scientific documentation and the development of the evaluation principle of FES (https://www.kwalis.de/).

\section{Sabrina Menestrina}

Sabrina was born in 1962 in Italy, where she lives and works as a veterinary doctor for the Italian healthcare service in central Friuli region. Among her various roles, she is responsible for health in beekeeping. In 2013, she founded, with Enrico Zagnoli, the biodynamic beekeeping section within the Italian Biodynamic Agriculture Association, for which she was General Secretary from 2011 to 2017. Since 2014, she has served on the board of the Italian Association of Anthroposophical Medicine, of which she is the Vice President. With friends and beekeepers, in 2016 she founded the Italian association ApiSophia to promote bees. In 2017, she co-founded the Anthroposophical Veterinary Medicine section within the Medical Section of the Goetheanum, in Dornach, Switzerland, of which she is the International Coordinator. She is also a board member of the new Biodynamic Federation Demeter International in Germany. She has presented many conferences on the health and dignity of bees and other animals.

\section{Joseph Milne}

Dr Joseph Milne is an Honorary Lecturer at the University of Kent where he taught on the MA course in Mysticism and Religious Experience until his retirement in 2013. His interests range from Platonism to medieval mysticism and theology, and in particular the transformations of metaphysical thought that have occurred at different times in Western civilisation. His current research is into the classical and medieval understanding of Natural Law. He is Editor of Land \& Liberty, the journal of the Henry George Foundation, and also a member of the team editing The Annotated Works of Henry George. He is the author of the Temenos Academy Papers: The Ground of Being: Foundations of Christian Mysticism (2004); Metaphysics and the Cosmic Order (2008); The Mystical Cosmos (2013); and The Lost Vision of Nature (2018). He is contributor of chapters to Mystical Theology and Continental Philosophy (ed. D. Lewin et al.; Routledge, 2017); to Peacefulness: Being Peace and Making Peace (eds. D. Cadman and S. Gill; Spirit of Humanity Press, 2017); and to The Harmony Debates: Exploring a Practical Philosophy for a Sustainable Future (edited by Nicholas Campion, University of Wales Trinity Saint David, 2020). He is a Trustee of The Eckhart Society and a Fellow of the Temenos Academy.

\section{Ed Moerman}

Ed Moerman was born the oldest of two children into a Dutch greenhouse grower's family. As a teenager, helping out his father with cucumber crops influenced his career plans and he changed his studies from electrical engineering to horticulture. After graduation (with a BSc in Horticulture), Ed started advising greenhouse growers (1980-1987) as a government consultant, and in 1988, he moved to Koppert Biological Systems and worked in various positions, including advising growers 
on integrated pest management, pioneering the development of new export markets in Mediterranean and African countries, developing packaging methods for the global transport of living beneficial insects, and acting as knowledge manager in various domains. In many of the roles at Koppert, Ed has worked on developing simple ways to support growers and advisors to better measure, understand and manage their (visible and invisible) biological systems. The challenge of making plant resilience measurable started Ed's search in the domain of bio-electronics. In 2017, the Koppert Foundation was established, for which Ed works (part-time) as Executive Manager. This foundation supports smallholder farmers with some resources and sharing the treasure of Koppert's practical knowledge. Ed is convinced that sharing knowledge and developing skills, including around agroecology, are essential on this journey for all stakeholders, and this will help farming as a business to gain popularity, not the least for young people (www.koppert.com).

\section{Eduardo Ortega Delgado}

Eduardo Ortega Delgado graduated from the University of Havana with a Bachelor's in Chemistry in 1969, a Master's in Agricultural Sciences in 1975 and a PhD in Biological Sciences in 1979. Since 1981, he has been Professor of Plant Physiology. He is author or co-author of 120 published papers in national and international journals, and author of two educational books, two scientific books and contributions to book chapters. Leader of national and international scientific projects, Eduardo has supervised 70 undergraduate, Master's and $\mathrm{PhD}$ theses. He has been an Invited Professor at universities in Angola, Argentina, Austria, Brazil, Canada, Germany, Mexico, Spain, the USA and Venezuela and is a member of Scientific Councils at the University of Havana and two other Cuban institutes. He received the National Award in Biochemistry in 2014 as well as other awards. His main scientific interests are physiology of plant microorganisms' interactions, abiotic stress and plant productivity.

\section{Victor Prévost}

Victor Prévost was educated in Biology at the University of Cergy-Pontoise, graduating as an Environmental Engineer from the Institut Supérieur de l'Environnement, and then gained a Master's Degree in Biology of Tropical Ecosystems at the University of Guadeloupe, French West Indies. Victor practised as an Environmental Engineering Consultant in Caraïbes Environnement, Guadeloupe. In 2010, he joined the activity of Genodics as a research partner affiliated with ERRMECe laboratory in the University of Cergy-Pontoise and started developing the hydric stress resistance in pea experimental model to investigate the effect of Genodics technology on peas. He joined the National Centre for Scientific Research (CNRS) as a Biology Engineer and developed a dynamic fluidic system designed to observe the interaction between human bone cells and pathogenic bacteria in real time under a confocal microscope (results published in 2019). With Genodics, he then consolidated the R\&D function of the company and developed research partnerships and scientific communications. In partnership with ERRMECe laboratory, he continued the experimentations on hydric stress in pea regulated by genodic effect (results published in September 2020).

\section{Michael J. Roads}

Michael Roads was born a farmer's son in Cambridgeshire, England, in 1937. From an early age, he discovered that he had a natural ability to communicate with the mineral, plant and animal kingdoms, and to travel beyond linear time and space. Over the last 60 years, he has actively continued to develop these abilities. Emigrating to Australia in the 1960s, he farmed for 12 years in Tasmania and then pulled up all roots and, with his family, travelled around the mainland. Following this, he spent 6 years as an organic farming consultant during which time he published books on organic gardening. Michael has since written 23 books on his experiences and explorations of metaphysical realities and higher dimensions, and 2019 marked his 30th year of travelling over five continents presenting inspirational events that enable many participants to experience profound shifts in 
consciousness. While he still occasionally speaks to farming audiences, he continues to write and speak prolifically on the 'Metaphysical World of Nature' and on 'Growing in Consciousness' (www. michaelroads.com).

\section{Sergio Rodríguez Rodríguez}

Sergio Florentino Rodríguez Rodríguez graduated as an agronomist in 1987 from the University of Matanzas, Cuba. Head of the Department of Genetic Improvement of the Sugar Cane Research Stations in the provinces of Granma and Ciego de Ávila, he gained a Master's in Agricultural Sciences in 1999 from the University of Granma and a Doctorate in Agricultural Sciences in 2008 from the same university. He became Professor at the University of Granma in 2013 and Director of International Relations from 2008 to 2017. He has published more than 25 scientific articles as author or co-author, and two book chapters. He has directed undergraduate, masters' and doctoral theses. Coordinator of several international projects, he has carried out research stays in Belgium, China, Spain and Argentina. His field of research and teaching is genetics, plant physiology and the use of statistics in research, and on the topics of stress due to soil flooding, physical and chemical treatments for seed priming in sugarcane, mulberry, rice and papaya crops. He is a reviewer of scientific journals including the HOLOS journal (web of science, http://www2.ifrn.edu. br), a member of scientific editorial committees, and coordinator of the Environment Management Master's at the University of Granma.

\section{Melissa Roussopoulos}

Since 2005, Melissa Roussopoulos has been pioneering, researching and running Nature Constellations, an experiential group methodology that provides insights and solutions for questions about human interactions with ecological systems. Clients have included farmers, landowners, agronomists, environmental groups and university agricultural departments, bringing issues from difficulties with domestic animals to planning complex agricultural projects to concerns about global environmental problems.

Melissa's Nature Constellations work draws on her training in Organisational and Family Constellations, both well-established methods, as well as her experience in a post with the nowhere foundation researching the application of Constellations into different professional fields. It is also informed by her interdisciplinary research into interspecies communication.

Her background is as an environmentalist, and she worked on multi-stakeholder approaches to sustainability issues at The Environment Council, a UK-based charity, as well as undertaking research projects for international NGOs and the Austrian government. She has an MSc in Natural Resource Management (University of Leicester) and a BA in History and Philosophy of Science (University of Cambridge) (www.forgottenconnections.org).

\section{Juan José Silva Pupo}

Graduating as an agronomist in 1989 at the Higher Institute of Agricultural Sciences of Bayamo (ISCAB), current University of Granma, Juan has 30 years of teaching experience. He gained his $\mathrm{PhD}$ in Agricultural Sciences from the University of Granma in 2006 and became Professor in 2008. He has since held the posts of Dean of the Faculty of Agricultural Sciences (2010-2012), Vice-rector for Research and Postgraduate Studies at the University of Granma (2012-2015), and Director of the Center for Plant Biotechnology Studies (2007-2010 and 2015-present). He is Coordinator of national and international projects, including Coordinator of the Master's Degree in Agricultural Biotechnology (2017-2020) and Coordinator of the UNESCO Chair in Agricultural Biotechnology for Local Development, approved in 2014 jointly by UNESCO and the University of Granma. He has given courses and conferences on agricultural biotechnology and project management in Ecuador, Colombia, Venezuela and Guatemala. A tutor of diploma, master's and doctorate research, he has participated in numerous symposia and congresses in Portugal, the Netherlands and Cuba. He is the coordinator of the International Workshop on Sustainable Agriculture and Plant 
Biotechnology, which is part of the Cuban Congress on Local Development and is held every 2 years at the University of Granma. He has published more than 40 articles as lead author and co-author.

\section{Anneloes Smitsman}

Anneloes is a visionary scientist, published author, futurist, system architect and global catalyst. She holds a Master's degree in Law and Judicial Political Sciences from Leiden University and received a degree of Doctor from Maastricht University, the Netherlands. Her research 'Into the Heart of Systems Change' addresses how to transform the dualistic systemic barriers via a 'Transition Plan to a Thrivability Civilisation'. Anneloes has a unique vision and understanding of the Cosmic architecture of life, which she applies in all of her initiatives. She is the author of the Amazon Bestseller Love Letters from Mother Earth - The Promise of a New Beginning, and a forthcoming book 'Future Humans' with Dr Jean Houston. Anneloes is passionate about empowering people in developing the future systems, capabilities and living vision for an evolutionary civilisation. She is the lead architect of the EARTHwise Tipping Point System and a powerful teacher of Evolutionary Leadership, Social Innovation and Transformational Change. Her unique programmes have empowered thousands of people and organisations from around the world. She is a member of the Evolutionary Leaders Circle (www.earthwisecentre.org).

\section{Angel De Souza-Torres}

Angel Rafael De Souza Torres was born on 1 August 1967 in Bayamo, Granma, Cuba. Prof De Souza-Torres obtained his MSc in Physics from the Faculty of Physics and Mathematics, University of Oriente, Santiago of Cuba, in 1990. Presently, Prof De Souza-Torres is working as Professor of Physics in Department of Physics and Mathematics, Faculty of Technical Sciences, Granma University, Bayamo, Granma. Prof De Souza-Torres' main area of research includes bioelectromagnetism and the effects of extremely low-frequency non-uniform magnetic fields (MFs) on seed vigour, plant growth, water relations, photosynthesis and yield of crops grown under abiotic, biotic and non-stress conditions. He also is investigating the tracking of iron oxide nanoparticles in plant organs using magnetic measurements and the impact of $\mathrm{Fe}_{3} \mathrm{O}_{4}$ nanoparticles on nutrient accumulation in common bean plants in collaboration with Institute of Physics, University of Sao Paulo, Brazil. He has been awarded a grant by Soleil Synchrotron, Paris, for a research cooperation project in collaboration with the European Synchrotron Radiation Facility, Grenoble, France. He has made major contributions in the field of bioelectromagnetism, especially in the improvement of germination, plant growth, water relations, photosynthesis, yield of tomato and onion crops and the protection of plants against heat stress and pathogens by MFs under field conditions. He has published several papers in high-impact journals and is a regular reviewer of 15 international journals. He was awarded the National Award of the Cuban Academy of Sciences in 2008 (www.udg.co.cu).

\section{Joël Sternheimer}

Joël Sternheimer holds a degree in Mathematics (Paris, 1964) and a PhD in Theoretical Physics (Lyon, 1966). His early research in theoretical physics was supported by income from his singersongwriting royalties, and he then undertook independent research on the masses of elementary particles, supervised by mathematical physicist André Lichnerowicz, a member of the Academy of Sciences. He has been involved in the development of various publications and patents, as well as giving seminars at the Collège de France. Since 1984, he has been scientific advisor on patent licensing to the Cité des Sciences et de l'Industrie, Paris, and from August 1985, has been working on applications related to the decoding of proteodies according to the method described in patent No. FR 92 06765 (filed in 1992), WO 1993/024645, which was published on 29 August 2007. From 1986 to 1988, he was Director of Seminars at the Collège International de Philosophie, Paris, co-organising the Colloquium 'Louis de Broglie, physicist and thinker', and since 1994 in a similar role at the European Research University, Paris. In 1999, he became Founding President of the Associative Network of Independent Researchers, and in the same year, he received the Philips-Science Front 
Award. He has implemented various agronomic applications, at the Nagata Agric. Research Institute, Japan, 2000-2003, and after that in France, in particular in viticulture, market gardening and oyster farming.

\section{Peter Stolz}

As an analytical chemist, Dr Peter Stolz is leading the institute KWALIS Qualitätsforschung, in Dipperz, Germany. He studied chemistry at the University of Bielefeld, Germany, from 1978 to 1986, and obtained his $\mathrm{PhD}$ (Dr. rer. nat.) from the chemistry department of the University of Oldenburg, Germany, in 1989. He worked at the Bremer Umweltinstitut, Germany, where his scientific and financial chairmanship lasted for 9 years. His cooperation and collaboration in the years 1998-2010 with Dr Jürgen Strube, who established the institute KWALIS, empowered him to continue the scientific work of Jürgen Strube and combine it with the knowledge of chemistry and the competence to work with modern analytical techniques. His concern to view food not only as the sum of single chemical substances, but as a whole that is integrated into life processes, has resulted in, among other things, the book Food Mediates Life (German: Lebensmittel vermitteln Leben), and this interest is present in all of his scientific activities (https://www.kwalis.de/).

\section{Jack Tuszyński}

Prof Tuszyński obtained his $\mathrm{PhD}$ in condensed matter physics in 1983 from the University of Calgary. From 1983 to 1988, he was a faculty member at the Department of Physics of the Memorial University of Newfoundland. He moved to the University of Alberta in 1988 as an assistant professor; between 1990 and 1993, he was an associate professor, and then full professor at the Department of Physics until now. Between 2005 and 2020, he held the prestigious Allard Chair in Experimental Oncology at the Cross Cancer Institute. He was also a Fellow of the National Institute for Nanotechnology of Canada. Dr Tuszyński held visiting professorship and research positions in China, Germany, France, Israel, Denmark, Belgium and Switzerland. He has published over 500 peer-reviewed journal papers and 12 books. He delivered almost 400 scientific talks at conferences on five continents, half of which were invited presentations. He submitted 21 patent applications and obtained 4 patents in the USA, South Korea, Japan and Singapore. His research has been supported by over 100 research grants from Canadian, US and European funding agencies. He is on the editorial board of almost 30 international journals including the Journal of Biological Physics. He is an Associate Editor of The Frontiers Collection at Springer-Verlag, Heidelberg. The major thrust of his computational biophysics group is in silico drug design for cancer chemotherapy applications.

\section{Medardo Ángel Ulloa Enríquez}

Medardo Ulloa Enríquez is a works engineer at the Equinoccial Technology University, Ecuador. He holds a Master's in Production Management and a Diploma in Didactics of Higher Education both from the Technical University of Cotopaxi, Ecuador. He also has a $\mathrm{PhD}$ in Technical Sciences from Oscar Lucero Moya, Holguín, Cuba. Director of productive projects at the Technical University of Cotopaxi (Ecuador), he has published more than 15 scientific articles and has tutored undergraduate and masters' theses. His research is based on the risks of work, quality systems and environmental aspects in different areas of research and production.

\section{Rovier Verdi}

As a rice grower's son, Rovier Verdi has worked his whole life with agriculture. After his graduation in agronomy, from 2010 to 2015 at the Catarinense Federal Institute of Education, Science and Technology, Rio do Sul, Brazil, he became interested in agroecology and got in contact for the first time with homeopathy for plants. There he studied homeopathy applied to medicinal plants. During 2016 and 2018, he did a master's degree in plant production at the Agroveterinary Science Centre of the Santa Catarina State University, Brazil (CAV/UDESC), working with the propagation of a Brazilian native medicinal plant (Poiretia latifolia) and homeopathy. Since then, he has been a member of the Laboratory 
of Homeopathy and Plant Health/Lages Experimental Station of EPAGRI, Brazil. During the same period, he took a specialisation on agroecology at the Santa Catarina Federal Institute of Education, Science and Technology, Lages, Brazil, working with homeopathy in rice crops. Nowadays he is doing a PhD in Plant Production at the CAV-UDESC and in Interdisciplinary Studies in Agroecology, Water and Resilience at the Centre for Agroecology, Water and Resilience of Coventry University, UK. He is working with eco-intensification of irrigated rice production where he is examining mainly the practices supported by the System of Rice Intensification method, innovative technologies such as homeopathy and biodynamics and a knowledge-intensive research methodology, based on a researcher-farmer participatory approach to improve the state of knowledge on sustainable rice production in Brazil. He is the Santa Catarina State representative for the Brazilian Association of Homeopathy for Agriculture, Livestock and Environment, as well as Editor of Brazilian Journal of Agroecology.

\section{Jenifer Wohlers}

The research focus of Jenifer Wohlers is on organic and biodynamic farming practice and agricultural scientific knowledge, commencing when she studied organic agriculture and undertook her $\mathrm{PhD}$ from the University of Kassel-Witzenhausen in Germany. Since 2011, she has been working as a scientist at the research institute KWALIS in Dipperz, Germany.

An important topic of her research is the evaluation of food quality from analytical as well as holistic quality aspects, in relation to both farming-relevant factors in organic agriculture and processing-relevant factors in food excellence, with the aim to develop food quality parameters which complement the established analytical parameters and may point to health and welfare aspects in food production situations (for both plants and animals), or point to improvements in consumer well-being (https://www.kwalis.de/). 